\title{
Cutaneous Myeloid Sarcoma of the Penile Foreskin
}

\author{
Sünnet Derisinin Myeloid Sarkomu
}

\author{
Ruquiya AFROSE ${ }^{1}$, Deepa NEBHNANI ${ }^{2}$, Neelam WADHWA ${ }^{1}$ \\ 'Department of Pathology, University College of Medical Sciences, DELHI, INDIA \\ 2 Department of Uro-Pathology, Seth G S Medical College and KEM Hospital, MUMBAI, INDIA
}

\begin{abstract}
Myeloid sarcoma, considered to herald the onset of a blast crisis in the setting of chronic myeloproliferative neoplasm/dysplasia, typically presents during the course of the disorder. Cutaneous involvement is uncommon and lesions on genital skin are seldom seen. We present a case of a well-differentiated myeloid sarcoma in the penile foreskin in an apparently healthy 29 -year-old male presenting with phimosis. The unusual composition of the inflammatory cell infiltrate, and characteristic sparing of dermal blood vessels, nerves and smooth muscle fibres led to the correct diagnosis. Absence of commonly observed changes in the circumcision skin like those of balanitis xerotica was also helpful. Detailed hematological work up revealed a previously undiagnosed chronic myeloid leukemia in chronic phase. The patient also had simultaneous priapism, another rare presentation of chronic myeloid leukemia. One year hence, the patient is in hematological remission with no evidence of extramedullary disease. Although priapism has been described as a rare presenting symptom in chronic myeloid leukemia, the present case is unique as this is the first time a cutaneous myeloid sarcoma has been documented in the penile foreskin.
\end{abstract}

Key Words: Myeloid leukemia, Chronic phase, Circumcision, Phimosis, Priapism
ÖZ

Kronik myeloproliferatif neoplazm/displazide blastik krizin habercisi olarak kabul edilen myeloid sarkom, hastalığın gidişatı sırasında sıklıkla ortaya çıkar. Deri tutulumu sık değildir, genital bölge derisi lezyonları çok az görülür. Bu makalede fimozis dışında yakınması olmayan 29 yaşında erkeğin sünnet derisindeki iyi diferansiye myeloid sarkom olgusu sunulmaktadır. Yangısal infiltrasyonun alışılmadık kompozisyonu ile dermal kan damarlarının, sinirlerin ve düz kas liflerinin karakteristik olarak korunmasına dikkat edilmesi doğru tanıya götürmüştür. Sünnet derisinde balanitis xeroticada sıklıkla görülenlere benzer değişikliklerin yokluğu da tanıda yardımcı olmuştur. Detaylı hematolojik çalışmalar daha önce tanı konmamış kronik fazdaki kronik myeloid lösemiyi ortaya çıkarmıştır. Hastada aynı zamanda, kronik myeloid löseminin bir diğer nadir ortaya çıkış biçimi olan eşzamanlı priapizm de bulunmaktaydı. Geçen bir yılda hasta, ekstramedüller hastalık belirtisi olmaksızın hematolojik remisyondadır. Her ne kadar priapizm kronik myeloid löseminin nadir başlangıç biçimlerinden biri olarak tanımlanmışsa da, olgumuz sünnet derisinde myeloid sarkomun ilk kez bildirilmesi açısından eşsizdir.

Anahtar Sözcükler: Myeloid lösemi, Kronik-faz, Sünnet, Fimozis, Priapizm

\section{INTRODUCTION}

Myeloid sarcoma (MS) refers to a rare solid tumor composed of immature myeloid cells at an extramedullary site (1). Most cases develop in the course of a leukemia; its presentation concurrent to or preceding leukemia is uncommon $(1,2)$. While its recognition is easy in the setting of a known hematologic malignancy, up to $75 \%$ of MS cases may be misdiagnosed (2). Cutaneous involvement is uncommon and lesions on the genital skin are seldom seen $(1,2-4)$. Priapism, sustained penile erection in the absence of physiologic stimuli, indicates the disturbance of the regulatory mechanisms responsible for penile erection and detumescence (5). It is an uncommon but well-documented complication of sickle cell disease but sparingly reported in leukemias (6). We report a case of simultaneous phimosis

(Turk Patoloji Derg 2015, 31:131-135)

Received : 26.05.2012 Accepted : 18.06.2012 with priapism as the first presentation of a previously undiagnosed case of chronic myeloid leukemia (CML). The present case is unique as a cutaneous MS was identified on histopathological examination of the circumcision specimen of the penile foreskin.

\section{CASE REPORT}

A 29-year-old uncircumcised male presented with the inability to retract the prepuce and sustained painful penile erection for the last 10 and 3 days, respectively. There was no history of trauma, previous episode of similar erection, flaccidity, or symptoms of urinary tract infection. The patient did not have a history of chronic medication or drug abuse, or heavy consumption of alcohol. There were no systemic complaints besides a history of easy fatigability

Correspondence: Neelam WADHWA

Department of Pathology, University College of Medical Sciences, DELHI, INDIA

E-mail: drneelam428@yahoo.co.in Phone: +91 11122582971 
for the past few weeks. Genital examination revealed an erect, tense and tender penis with a relatively softer glans. The overlying skin showed no discoloration. The prepuce could not be retracted from the glans penis. Abdominal examination revealed an enlarged spleen and liver that were palpable 5 and $2 \mathrm{~cm}$ below the left and right costal margins, respectively.

Routine biochemical and preliminary hematological investigations including a peripheral blood smear examination were performed. Color Doppler and abdominal ultrasound were also performed to assess penile blood flow and visceral organ size, respectively. The complete blood counts revealed marked leukocytosis (total leukocyte count $366.34 \times 10^{3} / \mathrm{L}$ ), anemia (hemoglobin $76 \mathrm{gm} / \mathrm{L}$ ) and thrombocytosis (platelet count $622 \times 10^{3} / \mathrm{L}$ ). Immature cells of myeloid lineage at all stages of maturation including myeloblasts (4\%) were seen in the peripheral blood smear; there was also basophilia (6\%). The hematological features were consistent with CML, chronic phase. The biochemical test results including blood sugar were non contributory. Color Doppler showed normal blood flow in the dorsal arteries but no flow in the cavernosal arteries, consistent with low flow/ischemic type priapism. Abdominal sonogram confirmed splenomegaly and hepatomegaly. Winter shunting procedure was performed under local analgesia to provide immediate relief to the patient and to reduce the risk of long term sequelae. Briefly, the corpora cavernosa were allowed to evacuate by shunts created by inserting a needle between them and corpora spongiosum. The stagnant blood could then exit the erect penis, leading

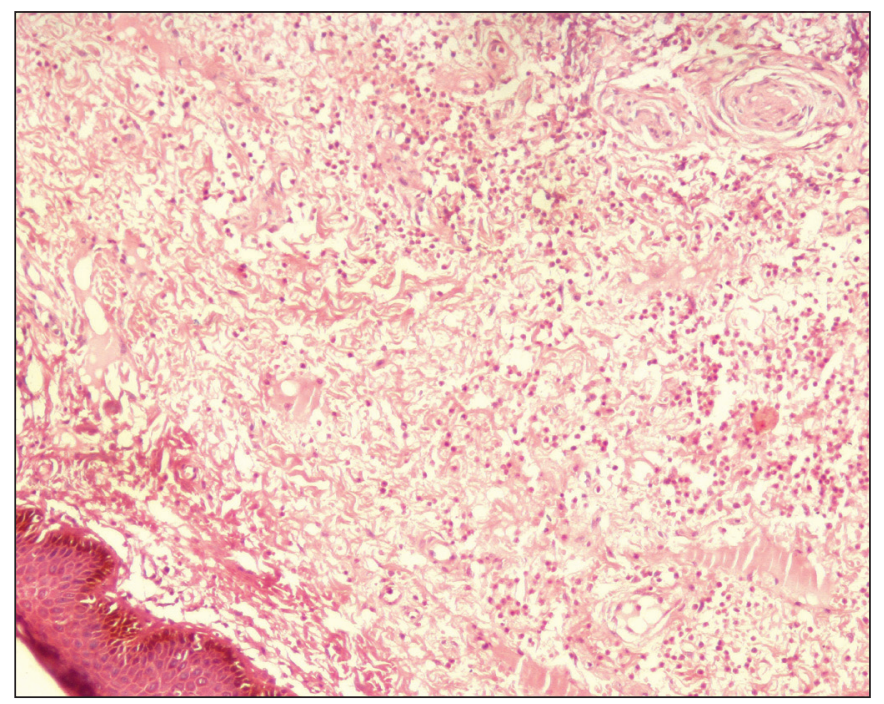

Figure 1: Diffuse infiltration of dermis by myeloid cells and dermal edema (H\&E; x100). to gradual detumescence. Circumcision was performed for the phimosis in the same setting. Analgesics and hydration were continued for the next week.

The excised foreskin was formalin fixed, processed routinely and 4 micron thick hematoxylin and eosin stained sections prepared. Myeloid cells at different stages of maturation were seen infiltrating the mid and deep dermis (Figure 1). The maturing myeloid cells could be identified easily owing to their nuclear lobation. The immature forms were few; they had round to oval nuclei with scant cytoplasm. Eosinophilic precursors had prominent cytoplasmic granules. The dermal vessels were characteristically uninvolved by the infiltrate and there was no evidence of vasculitis in the form of thrombosis, fibrinoid necrosis or leukocytoclasia in the vessel wall (Figure 2). Similarly, neither the dermal nerve bundles nor the smooth muscle fibres were infiltrated.

Megakaryocytes or erythroid precursors could not be identified. Immuno-staining with the standard avidin biotin method was performed for leukocyte common antigen (LCA), CD34 (for blasts), CD15 (for myeloid differentiation), CD20 and CD3 (for B and T lymphoid lineage respectively). The reaction for LCA and CD15 was strong and observed in almost all cells (Figure 3). This confirmed the myeloid differentiation observed on the hematoxylin and eosin stained sections. The results for $\mathrm{CD} 20$ and $\mathrm{CD} 3$ were expectedly negative. CD34 expression was occasional. There was no evidence of balanitis xerotica obliterans (BXO) in the form of epidermal changes, dermal hyalinization or fibrosis (Figure 4). A diagnosis of cutaneous MS of penile foreskin was made.

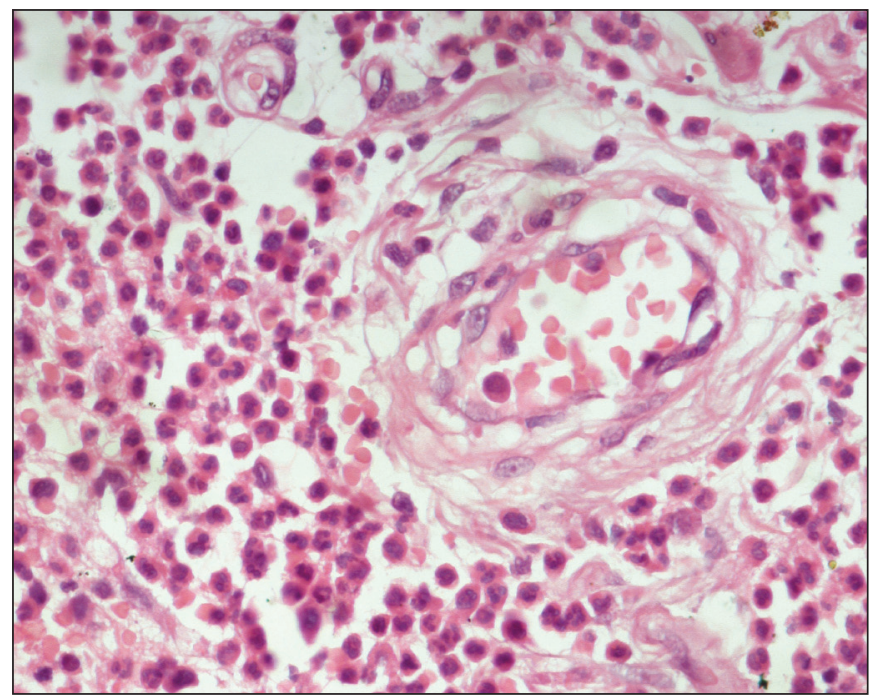

Figure 2: Myeloid cells at various stages of maturation are identified. Note that the blood vessels are characteristically uninvolved by the dense infiltrate of myeloid cells (H\&E; x400). 


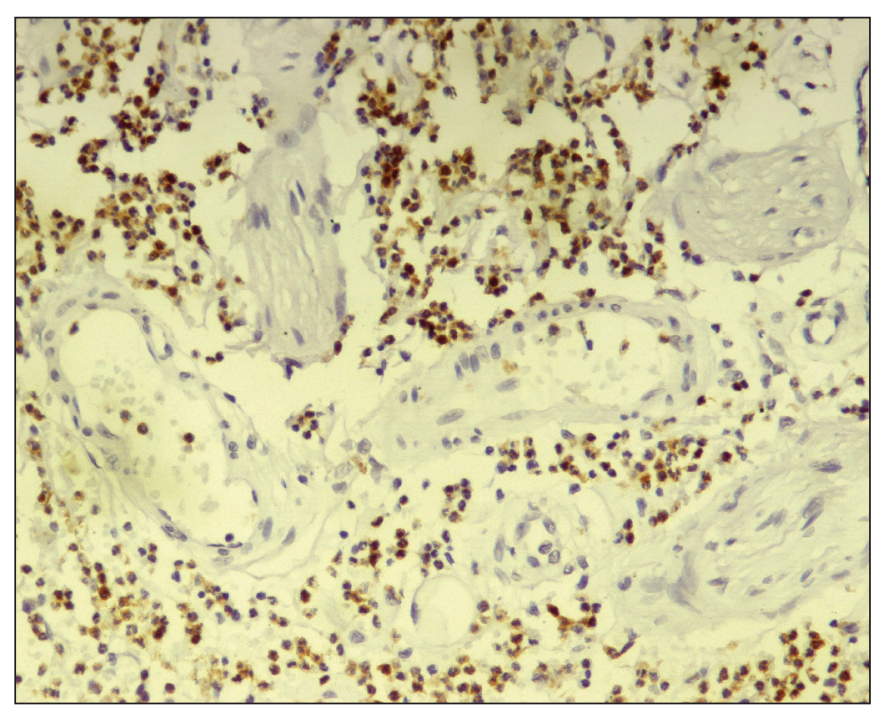

Figure 3: CD15 decorating almost all cells confirming the myeloid differentiation; the vascular sparing is highlighted (CD15; x200).

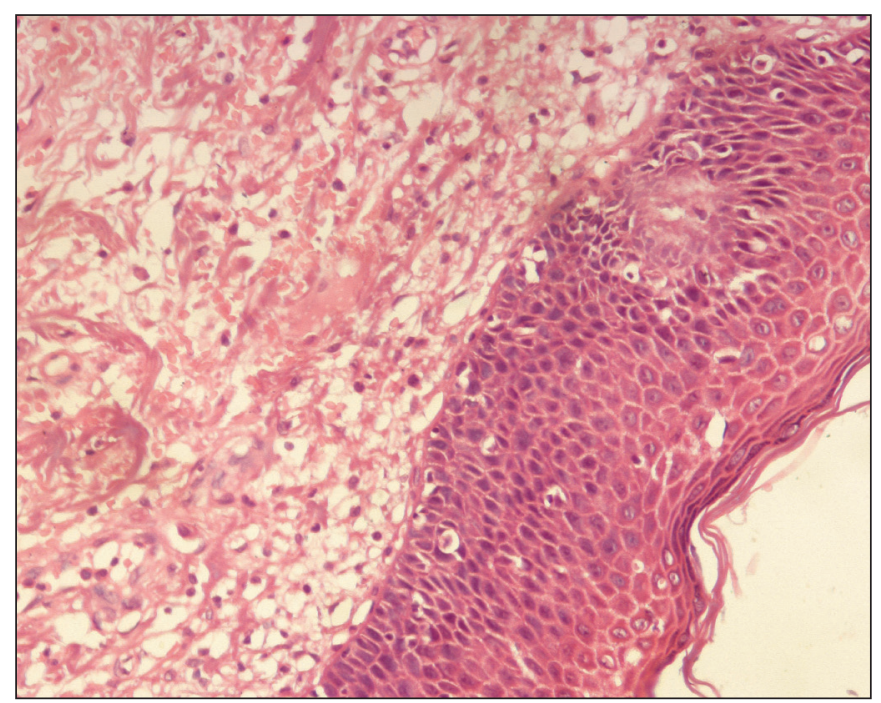

Figure 4: Essentially unremarkable epidermis; note absence of vacuolization of the basal layer (H\&E; x200).

Bone marrow aspiration, biopsy and fluorescence in situ hybridization (FISH) were also performed subsequently. The bone marrow was markedly hypercellular with reduction of fat spaces. There was preponderance of myeloid precursors and maturing forms outnumbered the blasts. The erythroid precursors were scanty and megakaryocytes numerous including abnormal forms. Using the LSI bcr/ abl dual color dual fusion probe (Vysis) for interphase FISH, 83.5\% (167/200) of the nuclei showed a fusion signal indicative of translocation $(9,22)$. Oral imatinib (400 $\mathrm{mg}$ /day) therapy was started and 12 months hence the patient is in hematological remission with no evidence of extramedullary disease.

\section{DISCUSSION}

MS refers to an extramedullary manifestation of a non lymphoid malignancy. Also called granulocytic sarcoma, it occurs more often in acute leukemia. Its presence in chronic myeloproliferative neoplasm/dysplasia heralds the onset of a blast crisis. Presentation concurrent or preceding a hematological malignancy, as happened in our case, is seen in only up to one third of the cases. Any site of the body can be affected, particularly the bone, soft tissues and lymph nodes $(1,2)$. The skin is an uncommon site of involvement; cutaneous lesions include erythematous to violaceous papules, nodules, plaques, or persistent non healing ulcer $(3,7)$. The legs are involved most often, followed by the arms, back, chest, scalp and face. Involvement of genital skin is very rare and only one case involving the scrotal skin has been described in the English literature (4).

Depending upon the degree of differentiation, MS is classified as well differentiated, poorly differentiated and blastic type (1). The presence of numerous maturing myeloid elements qualifies for the well differentiated category, as was the present case. These cases need to be distinguished from extramedullary hematopoiesis (EMH), small vessel vasculitis and infections $(1,8)$. MS differs from EMH in lacking erythroid and megakaryocytic cells. We did not find megakaryocytes or erythroid precursors despite extensive search. Cutaneous EMH is commoner in neonates where it is often associated with TORCH (toxoplasma, rubella, and herpes virus) infection (8). In adults, it is described mostly in myelofibrosis; although it may occur rarely in CML. New evidence suggests that cutaneous $\mathrm{EMH}$ in chronic myeloid disease should be considered as metastasis of the abnormal neoplastic cells and subsequent differentiation along divergent myeloid lineages (9). Recent demonstration of the characteristic Janus kinase 2 gene mutation in the cutaneous lesion of a patient with primary myelofibrosis also supports the metastasis hypothesis (10). Poorly differentiated MS cases have scanty maturing cells. Lesions lacking morphological evidence of myeloid differentiation are said to be blastic. The latter are likely to be confused with lymphoma infiltrate, poorly differentiated carcinoma and malignant melanoma; these cases require immunohistochemistry for the diagnosis $(1,3)$.

Recognition of MS is often straightforward In the setting of a known hematological malignancy. However, as many as three-fourths of MS cases may be misdiagnosed in the absence of this useful information (2). The well differentiated type of MS is likely to be overlooked as a benign inflammatory/infectious lesion owing to the presence of a large number of mature neutrophils. Blastic 
type MS is easily recognized as a malignant lesion, the issue being differentiation from other high-grade malignancies. Early chemotherapy in MS is known to improve survival outcome. Local therapy may improve symptoms but does not influence survival (11). Our patient received immediate chemotherapy and is doing well after one year.

Histopathology of the circumcision skin invariably reveals an inflammatory dermatosis: either a specific lesion like balanitis xerotica obliterans (BXO) or a chronic non specific infiltrate (12). BXO, the male variant of lichen sclerosus et atrophicus and limited to the genital regions, is a chronic inflammatory dermatosis characterized by basal layer vacuolization, hyalinization of dermal collagen and loss of elastic fibres. A history of diabetes mellitus should be sought in cases with a non specific inflammatory pattern (13). So far no case of phimosis has been demonstrated to harbor hematopoietic elements. This case is the first to histologically document a cutaneous MS in the phimosis circumcision foreskin specimen. Attention to the unusual composition of the inflammatory cell infiltrate, and the characteristic sparing of dermal blood vessels, nerves and smooth muscle fibres led to the correct diagnosis. Absence of commonly observed changes in circumcision skin such as the epidermal changes of balanitis xerotica was also helpful. The real etiology of phimosis in the present case remains obscure although it may be hypothesized that the dermal leukemic infiltration and edema made the skin thicker and rigid, making the physiological movement of the foreskin difficult. Rarely, cutaneous lesions harboring hematopoietic elements may show dermal sclerosis. The demonstration of transforming growth factor beta in the immature hematopoietic cells may explain the fibrogenic activity (14). However, there was no evidence of fibrosis in the present case. Phimosis is a well known manifestation of chronic graft versus host disease in male patients with hematological disease treated with allogenic bone marrow/ stem cell transplant. Suzuki et al reported phimosis in 15/46 (32.6\%) uncircumcised male patients under the age of 15 years treated with allogenic stem cell transplantation (15). However, the histopathological details of the circumcision skin are not mentioned in their report.

Priapism refers to sustained (more than 4 hours) penile erection in the absence of physiologic stimuli. Rare by itself in the healthy population, it is notably associated with sickle cell anemia (5). Male patients with CML may uncommonly also develop priapism. Its occurrence is more typical in the course of the evolution of CML rather than an initial presentation as happened in our case. It has been reported as the first complaint in only $3.2 \%$ of male CML patients (6). Hyperleukocytosis is a significant risk factor for developing priapism, as was present in our case. The sludging of the rigid leukemia cells in hyperleukocytosis states prevents the outflow of blood, resulting in failure of detumescence.

To conclude, we have reported an unusual presentation of a previously undiagnosed CML. This case is unique as it is the first time a cutaneous MS has been demonstrated in a phimosis circumcision foreskin specimen. Features suspicious of myeloid sarcoma were the unusual composition of dermal infiltrate, absence of erythroid precursors, megakaryocytes and characteristic sparing of dermal vessels and nerves.

\section{REFERENCES}

1. Neiman RS, Barcos M, Berard C, Bonner H, Mann R, Rydell RE, Bennett JM. Granulocytic sarcoma: A clinicopathologic study of 61 biopsied cases. Cancer. 1981;48:1426-37.

2. Meis JM, Butler JJ, Osborne BM, Manning JT. Granulocytic sarcoma in nonleukemic patients. Cancer. 1986;58:2697-709.

3. Cho-Vega JH, Medeiros LJ, Prieto VG, Vega F. Leukemia cutis. Am J Clin Pathol 2008;129:130-42.

4. Zax RH, Kulp-Shorten CL, Callen JP. Leukemia cutis presenting as a scrotal ulcer. J Am Acad Dermatol. 1989;21:410-3.

5. Bassett J, Rajfer J. Diagnostic and therapeutic options for the management of ischemic and nonischemic priapism. Rev Urol. 2010;12:56-63.

6. Savage DG, Szydlo RM, Goldman JM. Clinical features at diagnosis in 430 patients with chronic myeloid leukaemia seen at a referral centre over a 16-year period. Br J Haematol. 1997;96:111-6.

7. Wadhwa N, Batra M, Singh B. Nonhealing ulcer-A rare initial presentation of chronic myeloid leukemia diagnosed on aspiration cytology. Diagn Cytopathol. 2011;39:135-7.

8. Smoller BR. Other lymphoproliferative and myeloproliferative diseases. In: Bolognia J, Jorizzo JL, Rapini RP, editors. Dermatology. Vol: 2. 2nd ed. Spain: Mosby Elsevier; 2008: 1887-96.

9. Haniffa MA, Wilkins BS, Blasdale C, Simpson NB. Cutaneous extramedullary hemopoiesis in chronic myeloproliferative and myelodysplastic disorders. J Am Acad Dermatol. 2006;55:S28-31.

10. Fraga GR, Caughron SK. Cutaneous myelofibrosis with JAK2 V617F mutation: Metastasis, not merely extramedullary hematopoiesis. Am J Dermatopathol. 2010;32:727-30.

11. Lan TY, Lin DT, Tien HF, Yang RS, Chen CY, Wu K. Prognostic factors of treatment outcomes in patients with granulocytic sarcoma. Acta Haematol. 2009;122:238-46.

12. Jasaitiene D, Valiukeviciene S, Vaitkiene D, Jievaltas M, Barauskas V, Gudinaviviene I, Fanke I, Gollnick H. Lichen sclerosus et atrophicus in pediatric and adult male patients with congenital and acquired phimosis. Medicina (Kaunas). 2008;44:460-6. 
13. Bromage SJ, Crump A, Pearce I. Phimosis as a presenting feature of diabetes. BJU Int . 2008;101:338-40.

14. Kawakami T, Kimura S, Kato M, Mizoguchi M, Soma Y. Transforming growth factor-beta overexpression in cutaneous extramedullary hematopoiesis of a patient with myelodysplastic syndrome associated with myelofibrosis. J Am Acad Dermatol. 2008;58:703-6.

15. Suzuki D, Kobayashi R, Kaneda M, Sato T, Ichikawa M, Ariga T. Severe phimosis as a notable sequela of allogeneic stem cell transplantation in boys. Bone Marrow Transplant. 2007;40:335-8. 